FIELD NOTE

\title{
Longitudinal and geographic variations in the green moisture content and basic density of bamboo culm in three species naturally grown in Lombok Island, Indonesia
}

\author{
Dwi Sukma Rini ${ }^{1,2,3}$, Futoshi Ishiguri ${ }^{1^{*}}$, Ikumi Nezu ${ }^{1,2}$, Irwan Mahakam Lesmono Aji ${ }^{3}$, Denny Irawati ${ }^{4}$, \\ Jyunichi Ohshima ${ }^{1}$ and Shinso Yokota ${ }^{1}$ \\ ${ }^{1}$ School of Agriculture, Utsunomiya University, Utsunomiya, Tochigi 321-8505, Japan \\ ${ }^{2}$ United Graduate School of Agricultural Science, Tokyo University of Agriculture and Technology, Fuchu, Tokyo 183-8509, \\ Japan \\ ${ }^{3}$ Department of Forestry, University of Mataram, Mataram 83125, Indonesia \\ ${ }^{4}$ Faculty of Forestry, Universitas Gadjah Mada, Yogyakarta 55281, Indonesia \\ * Corresponding author: ishiguri@cc.utsunomiya-u.ac.jp
}

Received: July 28, 2021 Accepted: October 31, $2021 \quad$ J-STAGE Advance published date: February 1, 2022

\begin{abstract}
Longitudinal and geographic variations in the green moisture content and basic density of bamboo culm were evaluated by using linear mixed-effect models for three bamboo species (Bambusa vulgaris Schrad. ex J.C., Bambusa maculata Widjaja, and Gigantochloa atter (Hassk) Kurz ex Munro) naturally grown in four locations in Lombok Island, Indonesia. The mean green moisture contents and basic densities were $74.2 \%$ and $0.69 \mathrm{~g} \mathrm{~cm}^{-3}$ for B. vulgaris, $78.5 \%$ and $0.65 \mathrm{~g} \mathrm{~cm}^{-3}$ for B. maculata, and $80.3 \%$ and $0.65 \mathrm{~g} \mathrm{~cm}^{-3}$ for $\mathrm{G}$. atter, respectively. No significant differences in green moisture content and basic density were found among the species. A significant negative correlation between basic density and green moisture content was found in all three species. Based on the results of model selections for longitudinal variations, the green moisture content decreased with an increase in the culm height in all three species, and basic density tended to increase from the base to the top of the culm. Relatively large geographical variation was found in the green moisture content and basic density of G. atter, although the main reasons for variation of these properties were individual culm in three species.
\end{abstract}

Key words: Bambusa vulgaris, Bambusa maculata, Gigantochloa atter, longitudinal variation, mixed-effects model

\section{INTRODUCTION}

Lombok Island is located in central part of Indonesia and is belonging to West Nusa Tenggara. Because more than $80 \%$ of the forest area is classified as protected forest or conservation forest (Bae et al. 2014), utilization of wood from the forest are limited in this island. Thus, local people in Lombok Island needs to find substitute materials of wood for producing handicrafts, furniture, construction, and others.

Bamboo is a fast-growing plant (Kleinhenz and Midmore 2001, Liese and Kohl 2015, Wang et al. 2016) and is considered a substantial biomaterial (Peng and She 2014, Huang et al. 2015, Liese and Kohl 2015). Bamboo has traditionally been used for handicraft making, furniture and house construction (van Dam et al. 2018). Recently, bamboo has also been used in a wide range of engineering and civil construction applications (van der Lugt et al. 2006, Tan et al. 2011, Chaowana 2013, Sharma et al. 2015,
Liu et al. 2020, Aguinsatan et al. 2019). To create the more value-added products such as modern civil construction materials, bamboo culm properties should be clarified. Up to date, bamboo culm properties have been investigated for some tropical bamboo species, such as Dendrocalamus strictus, Dendrocalamus giganteus, Dendrocalamus asper, Bambusa blumeana, Bambusa vulgaris, Bambusa balcoa, Bambusa tulda, Gigantochloa scortechinii, Gigantochloa atter, and Gigantochloa levis (Liese 1987, Mohmod et al. 1990, Hisham et al. 2006, Kamruzzaman et al. 2008, Wahab et al. 2010, Marsoem et al. 2015, Wang et al. 2016, Zakikhani et al. 2017, Aguinsatan et al. 2019, Nordahlia et al. 2019). Unfortunately, no available information about bamboo culm properties was found in B. vulgaris, $B$. maculata, and $G$. atter which natively grown in Lombok Island and traditionally used for local products. To create the value-added new products based on bamboo instead of traditional local products such as handicrafts and others for developing local economy, detailed bamboo culm properties 
should be clarified in these native bamboo species grown in Lombok Island.

It is known that bamboo properties varied along the longitudinal direction within the whole culm (Grosser and Liese 1971, Anokye et al. 2014, Marsoem et al. 2015, Vetter et al. 2015). For example, Anokye et al. (2014) reported that the moisture content decreased and the shrinkage increased along the culm from basal to the top section of $G$. scortechinii growing in Malaysia. In addition, bamboo culm properties have geographic variations (Yang et al. 2009, Wang et al. 2016). Wang et al. (2016) examined the fiber morphology and amounts of chemical components in $D$. giganteus collected from three different locations in China. They concluded significant differences in fiber morphologies among the three locations. Therefore, the longitudinal and geographical variations of bamboo culm properties should be clarified to effectively utilize bamboo culm resources.

The objective of this study was to investigate the longitudinal and geographic variations in the green moisture content and basic density of bamboo culm in three native species in Lombok Island, Indonesia.

\section{MATERIALS AND METHODS}

\section{Experimental sites}

Culms of three- to four-year-old B. vulgaris, B. maculata, and G. atter were collected from Tempos (Site I), Kabul (Site II), Keruak (Site III), and Genggelang (Site IV) in Lombok Island, Indonesia (Fig. 1). The climatic conditions of each site are shown in Fig. 1. All the bamboos used in this study were naturally grown in the four sites. No silvicultural treatments, such as fertilizing or watering, were applied at all sites before sampling. Ten individual culms in each species at each site were cut at $20 \mathrm{~cm}$ above the ground. Thus, a total of 120 culms were obtained from the three species at the four sites. Table 1 shows the culm diameter of $1.3 \mathrm{~m}$ above the ground, culm thickness, and culm height. After cutting the culm, approximately $3 \mathrm{~cm}$ thick sample disks were obtained at 2-m intervals from $2 \mathrm{~m}$ to $8 \mathrm{~m}$ above the ground to determine the green moisture contents and basic densities.

\section{Green moisture content and basic density}

Four small specimens $(2.5[\mathrm{~T}] \mathrm{cm}$ by $2.5[\mathrm{~L}] \mathrm{cm}$ with varied culm thicknesses in radial direction) were prepared from various disk circumferences. Finally, 1,920 small specimens were obtained (four specimens $\times$ four heights $\times$ ten individuals $\times$ three species $\times$ four sites). The weight and volume in the green condition of the specimens were measured. Green volume was measured via a water displacement method (Barnett and Jeronimidis 2003). Then, the specimens were weighed after drying in an oven at 103 $\pm 2{ }^{\circ} \mathrm{C}$ for $48 \mathrm{~h}$.

\section{Statistical analysis}

Statistical analysis was conducted using R software ver. 4.0.3 ( $\mathrm{R}$ Core Team 2020). The mean value in each culm was calculated by averaging the values obtained from 16 specimens (four specimens by four heights). Longitudinal variations in the green moisture content and basic density were evaluated by developing a linear mixed-effect model using the lme4 package in $\mathrm{R}$ software ver.4.0.2 (Bates et al. 2015). The full model is expressed as:

$$
\begin{aligned}
Y_{i j k}= & \left(\beta_{0}+\text { Site }_{0 k}+\text { Culm }_{0 j k}\right) X_{i j k}+\beta_{1} \\
& + \text { Site }_{1 k}+\text { Culm }_{1 j k}+e_{i j k}
\end{aligned}
$$

where $Y_{i j k}$ is the bamboo property (green moisture content or basic density) at the $i$ th height position from the $j$ th individual culm within the $k$ th site, $\beta_{0}$ is the fixed slope, $\beta_{1}$ is the fixed intercept, $X_{i j k}$ is the $i$ th height position from the $j$ th individual culm within the $k$ th site. Site $e_{0 k}$ and Site $e_{1 k}$ are the random slope and intercept of the $k$ th site, $C u l m_{0 j k}$ and $C u l m_{1 j k}$ are the random slope and intercept of the $j$ th individual culm within the $k$ th site, and $e_{i j k}$ is the residual. Total 15 models were developed, and then the best model was determined based on the Akaike information criterion (AIC) (Akaike 1998); that is, the model with the minimum AIC is preferred. In addition, the differences in AIC ( $\triangle \mathrm{AIC})$ $\leq 2$ indicate no significant difference between models, and a simpler model with fewer parameters is preferred (Burnham and Anderson 2004). The significances of the fixed-effect parameters of the best model were determined using the lmerTest package (Bates et al. 2015).

Geographic variations in green moisture content and basic density were estimated by evaluating the variance component of sites as random effect by using the interceptonly linear mixed-effects model. The model is described as follows:

$Y_{i j k}=\mu+$ Site $_{k}+$ Culm $_{j k}+e_{i j k}$

where $Y_{i j k}$ is the bamboo property at the $i$ th height position of the $j$ th individual culm within $k$ th site, $\mu$ is the model intercept or grand mean, Site $_{k}$ is the random effect of the $k$ th 

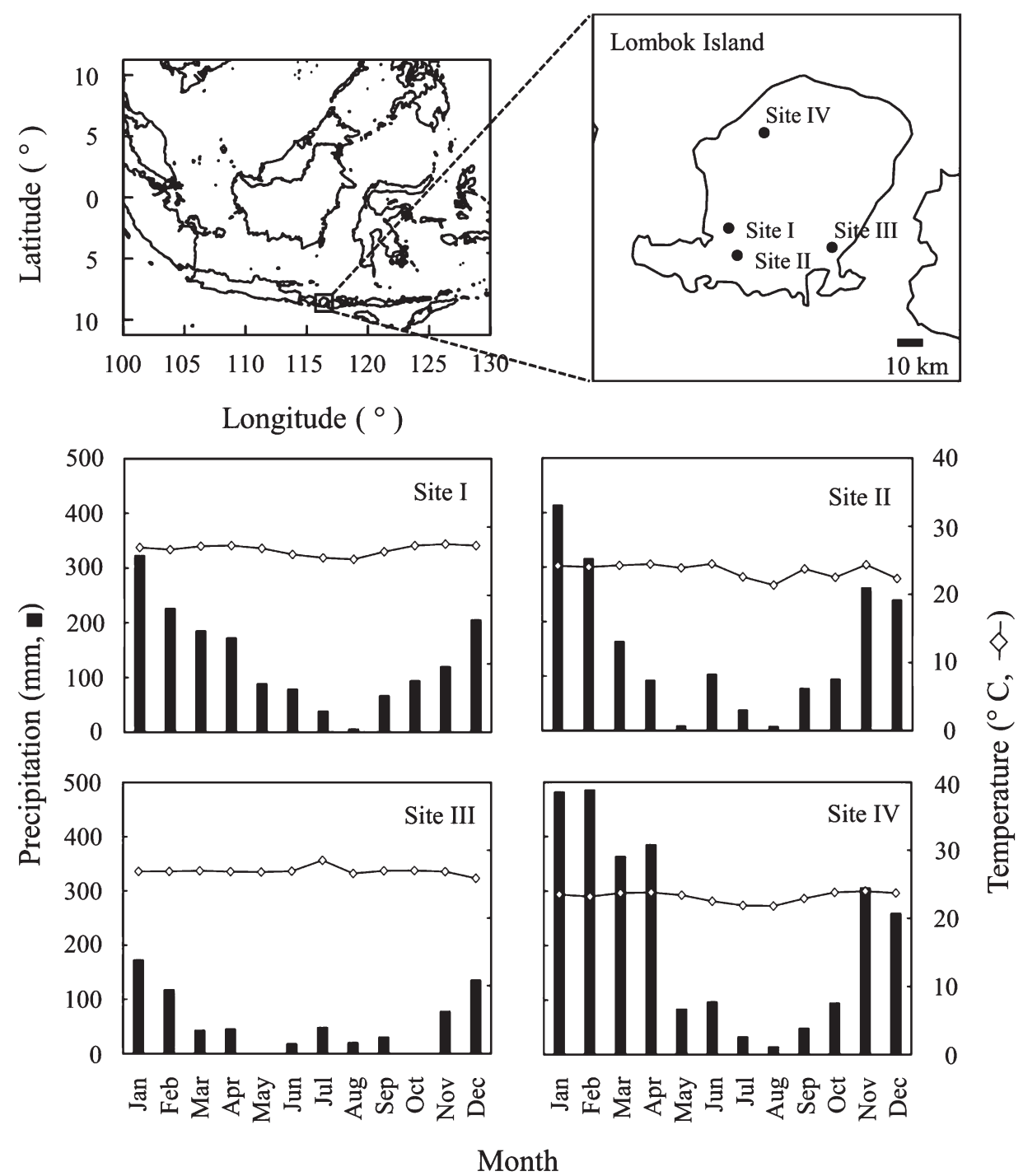

Fig. 1. Locations and climate conditions of sampling sites in the present study.

Note: Site I, Tempos ( $\left.8^{\circ} 41^{\prime} 59^{\prime \prime} \mathrm{S}, 116^{\circ} 8^{\prime} 40^{\prime \prime} \mathrm{E}\right)$; Site II, Kabul ( $\left.8^{\circ} 47^{\prime} 21^{\prime \prime} \mathrm{S}, 116^{\circ} 10^{\prime} 21^{\prime \prime} \mathrm{E}\right)$; Site III, Keruak $\left(8^{\circ} 45^{\prime} 45^{\prime \prime} \mathrm{S}, 116^{\circ} 28^{\prime} 54^{\prime \prime} \mathrm{E}\right)$; Site IV, Genggelang ( $\left.8^{\circ} 23^{\prime} 16^{\prime \prime} \mathrm{S}, 116^{\circ} 15^{\prime} 35^{\prime \prime} \mathrm{E}\right)$. Climate data were provided from Nusa Tenggara River Basin Management I, Indonesia. Mean monthly temperature and precipitation were calculated by averaging monthly values from 2016 to 2018 . Diamonds indicate the mean values of temperature. Bars indicate the mean values of precipitation.

site, $C u l m_{j k}$ is random effect of $j$ th individual culm within $k$ th site, and $e_{i j k}$ is the residual. The contribution of each level of variation was calculated as a percentage of the total random variation in the best model (Wilhelmsson et al. 2002, Auty et al. 2013).

A Tukey-Kramer test was applied for detecting the among-species differences in growth characteristics, green moisture content, and basic density. The mean values of each individual culm were used for the Tukey-Kramer test.

\section{RESULTS AND DISCUSSION}

\section{Growth characteristics}

The growth characteristics of the three bamboo species at each site are presented in Table 1. The highest mean culm diameters were recorded in G. atter (ranged from $7.9 \mathrm{~cm}$ to $9.4 \mathrm{~cm}$ ), followed by B. vulgaris (ranged from $6.8 \mathrm{~cm}$ to $8.0 \mathrm{~cm}$ ) and $B$. maculata (ranged from $6.3 \mathrm{~cm}$ to $8.0 \mathrm{~cm}$ ) (Table 1). The mean culm height and thickness values of $B$. vulgaris, B. maculata, and G. atter ranged from $13.59 \mathrm{~m}$ to $17.53 \mathrm{~m}$ and $0.66 \mathrm{~cm}$ to $0.90 \mathrm{~cm}, 14.77 \mathrm{~m}$ to $16.78 \mathrm{~m}$ and $0.56 \mathrm{~cm}$ to $0.81 \mathrm{~cm}$, and $14.92 \mathrm{~m}$ to $18.10 \mathrm{~m}$ and $0.49 \mathrm{~cm}$ to 
Table 1. Mean values of diameter, height, and culm thickness of three bamboo species.

\begin{tabular}{|c|c|c|c|c|c|c|c|c|}
\hline \multirow{2}{*}{ Species } & \multirow{2}{*}{ Site } & \multirow{2}{*}{$n$} & \multicolumn{2}{|c|}{$\mathrm{CD}(\mathrm{cm})$} & \multicolumn{2}{|c|}{$\mathrm{CH}(\mathrm{m})$} & \multicolumn{2}{|c|}{$\mathrm{CT}(\mathrm{cm})$} \\
\hline & & & Mean & SD & Mean & $\mathrm{SD}$ & Mean & SD \\
\hline \multirow{5}{*}{$\begin{array}{c}\text { Bambusa } \\
\text { vulgaris }\end{array}$} & I & 10 & 8.0 & 0.2 & 17.53 & 1.38 & 0.90 & 0.12 \\
\hline & II & 10 & 8.0 & 0.2 & 15.18 & 1.90 & 0.66 & 0.06 \\
\hline & III & 10 & 6.8 & 0.4 & 15.92 & 1.78 & 0.76 & 0.05 \\
\hline & IV & 10 & 7.1 & 0.2 & 13.59 & 1.56 & 0.85 & 0.12 \\
\hline & Mean & 40 & $7.5^{\mathrm{b}}$ & 0.6 & $15.55^{\mathrm{b}}$ & 2.15 & $0.86^{\mathrm{a}}$ & 0.10 \\
\hline \multirow{5}{*}{$\begin{array}{l}\text { Bambusa } \\
\text { maculata }\end{array}$} & I & 10 & 8.0 & 0.2 & 16.78 & 1.63 & 0.61 & 0.09 \\
\hline & II & 10 & 7.7 & 0.4 & 14.91 & 1.71 & 0.74 & 0.06 \\
\hline & III & 10 & 6.3 & 0.3 & 14.77 & 1.45 & 0.81 & 0.06 \\
\hline & IV & 10 & 7.0 & 0.6 & 16.41 & 1.49 & 0.56 & 0.05 \\
\hline & Mean & 40 & $7.3^{\mathrm{b}}$ & 0.8 & $15.72^{\mathrm{ab}}$ & 1.76 & $0.58^{\mathrm{c}}$ & 0.09 \\
\hline \multirow{5}{*}{$\begin{array}{c}\text { Gigantochloa } \\
\text { atter }\end{array}$} & I & 10 & 9.3 & 0.4 & 18.10 & 1.39 & 0.68 & 0.06 \\
\hline & II & 10 & 9.4 & 0.3 & 16.42 & 2.01 & 0.87 & 0.08 \\
\hline & III & 10 & 7.9 & 0.4 & 14.92 & 1.44 & 0.49 & 0.04 \\
\hline & IV & 10 & 8.4 & 0.2 & 17.05 & 2.03 & 0.77 & 0.06 \\
\hline & Mean & 40 & $8.7^{\mathrm{a}}$ & 0.7 & $16.62^{\mathrm{a}}$ & 2.04 & $0.74^{\mathrm{b}}$ & 0.07 \\
\hline
\end{tabular}

Note: $n$, number of individual culms; $\mathrm{CD}$, culm diameter at $1.3 \mathrm{~m}$ above the ground; $\mathrm{CH}$, culm height; CT, mean value of culm thickness from those at four height positions; SD, standard deviation. The same alphabet letters after mean values of each species indicate no significant differences at $p<0.05$ among three species by Tukey-Kramer test.

$0.87 \mathrm{~cm}$, respectively (Table 1). Bamboo has various growth characteristics among its species (Akinlabi et al. 2017, Nordahlia et al. 2019). Each bamboo species has distinct absolute characteristics, such as its culm height, internode length, and culm thickness (Nordahlia et al. 2019). Based on the results, the growth characteristics of the three bamboo species could be summarized as follows: 1) the two Bambusa species had similar culm sizes (diameter and height) but differing culm thicknesses, 2) B. vulgaris had the thickest culm among the three species, and 3) G. atter had the largest culm size among the three species but had thinner culm compared with B. vulgaris.

\section{Green moisture content and basic density}

Table 2 shows the mean green moisture content and basic density values of the three bamboo species at each site. The mean green moisture content values of B. vulgaris, B. maculata, and G. atter ranged from $65.7 \%$ to $79.4 \%$, $72.5 \%$ to $88.9 \%$, and $69.0 \%$ to $95.7 \%$, respectively. The mean basic density values of B. vulgaris, B. maculata, and $G$. atter ranged from $0.66 \mathrm{~g} \mathrm{~cm}^{-3}$ to $0.74 \mathrm{~g} \mathrm{~cm}^{-3}, 0.62 \mathrm{~g} \mathrm{~cm}^{-3}$ to $0.68 \mathrm{~g} \mathrm{~cm}^{-3}$, and $0.59 \mathrm{~g} \mathrm{~cm}^{-3}$ to $0.71 \mathrm{~g} \mathrm{~cm}^{-3}$, respectively (Table 2). No significant differences in the mean values of both properties were found among the three species (Table
2). With a few exceptions, the mean green moisture content and basic density values in the present study were within the range of those reported in previous studies (Table 3; Hisham et al. 2006, Wahab et al. 2010, Anokye et al. 2014, Marsoem et al. 2015, Ogunsanwo et al. 2015, Nordahlia et al. 2019).

Relationships found between green moisture content and basic density are shown in Fig. 2. Green moisture content was negatively correlated with basic density in all three species. Similar results were obtained in many bamboo species (Hisham et al. 2006, Wahab et al. 2010, 2012, Sharma et al. 2017).

\section{Longitudinal variations}

Tables 4 and 5 show the rank of linear mixed-effects models of longitudinal variations in the three bamboo species of green moisture content and basic density in relation to AIC values. For the longitudinal variation of green moisture content and basic density, the model with random slope and intercept of individual culm was selected as the best model in all species with few exceptions (Tables 4 and 5). In addition, the best model also included the site of random intercept for both properties in G. atter, whereas the site was neither random slope nor intercept of the best 
Table 2. Mean values of green moisture content and basic density of three bamboo species.

\begin{tabular}{|c|c|c|c|c|c|c|}
\hline \multirow{2}{*}{ Species } & \multirow{2}{*}{ Site } & \multirow{2}{*}{$n$} & \multicolumn{2}{|c|}{ Green moisture content $(\%)$} & \multicolumn{2}{|c|}{ Basic density $\left(\mathrm{g} \mathrm{cm}^{-3}\right)$} \\
\hline & & & Mean & SD & Mean & SD \\
\hline \multirow{5}{*}{$\begin{array}{c}\text { Bambusa } \\
\text { vulgaris }\end{array}$} & I & 10 & 74.1 & 9.5 & 0.67 & 0.05 \\
\hline & II & 10 & 77.6 & 23.7 & 0.69 & 0.10 \\
\hline & III & 10 & 79.4 & 17.4 & 0.66 & 0.07 \\
\hline & IV & 10 & 65.7 & 17.6 & 0.74 & 0.08 \\
\hline & Mean & 40 & $74.2^{\mathrm{a}}$ & 17.9 & $0.69^{\mathrm{a}}$ & 0.08 \\
\hline \multirow{5}{*}{$\begin{array}{l}\text { Bambusa } \\
\text { maculata }\end{array}$} & I & 10 & 88.9 & 17.3 & 0.62 & 0.07 \\
\hline & II & 10 & 77.6 & 17.9 & 0.66 & 0.08 \\
\hline & III & 10 & 72.5 & 18.1 & 0.67 & 0.09 \\
\hline & IV & 10 & 74.9 & 14.1 & 0.68 & 0.06 \\
\hline & Mean & 40 & $78.5^{\mathrm{a}}$ & 17.5 & $0.65^{\mathrm{a}}$ & 0.08 \\
\hline \multirow{5}{*}{$\begin{array}{c}\text { Gigantochloa } \\
\text { atter }\end{array}$} & I & 10 & 79.4 & 17.6 & 0.66 & 0.07 \\
\hline & II & 10 & 77.3 & 22.1 & 0.66 & 0.08 \\
\hline & III & 10 & 95.7 & 16.9 & 0.59 & 0.06 \\
\hline & IV & 10 & 69.0 & 10.4 & 0.71 & 0.05 \\
\hline & Mean & 40 & $80.3^{\mathrm{a}}$ & 19.3 & $0.65^{\mathrm{a}}$ & 0.08 \\
\hline
\end{tabular}

Note: $n$, number of individual culms; SD, standard deviation. The same alphabet letters after mean values of each species indicate no significances at $p<0.05$ among three species by Tukey-Kramer test.

Table 3. Comparisons of green moisture content and basic density of Bambusa and Gigantochloa species in previous studies.

\begin{tabular}{|c|c|c|c|c|c|}
\hline Genus & Species & $\begin{array}{c}\text { Age } \\
\text { (year) }\end{array}$ & $\begin{array}{l}\text { MC } \\
(\%)\end{array}$ & $\begin{array}{c}\mathrm{BD} \\
\left(\mathrm{g} \mathrm{cm}^{-3}\right)\end{array}$ & References \\
\hline \multirow{4}{*}{ Bambusa } & \multirow{4}{*}{ B. vulgaris } & 4 & 88.9 & 0.66 & Wahab et al. (2010) \\
\hline & & 4 & ND & 0.61 & Nordahlia et al. (2019) \\
\hline & & $5-6$ & ND & 0.72 & Ogunsanwo et al. (2015) \\
\hline & & 4 & 96.0 & ND & Anokye et al. (2014) \\
\hline \multirow{4}{*}{ Gigantochloa } & G. atter & 3 & 112.3 & 0.59 & Marsoem et al. (2015) \\
\hline & \multirow{3}{*}{ G. scortechinii } & 3.5 & 65.4 & 0.61 & Hisham et al. (2006) \\
\hline & & 4 & 89.1 & ND & Anokye et al. (2014) \\
\hline & & 4 & ND & 0.64 & Nordahlia et al. (2019) \\
\hline
\end{tabular}

Note: MC, green moisture content; $\mathrm{BD}$, basic density; ND, no available data.

models in B. maculata (Tables 4 and 5). These results indicate that 1 ) the longitudinal variations of all species were dependent on the individual culm with few exceptions, and 2) the sites were affected on longitudinal variation in $G$. atter, but not in B. maculata.

Table 6 shows the fixed-effect parameters for the selected model. The fixed-effect parameters were significant for all parameters, except for the fixed slope of basic density in B. vulgaris. Fig. 3 shows the longitudinal variations in the green moisture content and basic density of the three bamboo species used in the present study. A regression formula was obtained using a linear mixedeffects model with minimum AIC values among developed models (Tables 4 and 5). Green moisture content decreased with an increase in the culm height for all three species. The same longitudinal patterns of green moisture contents were also found in B. vulgaris grown in Malaysia (Wahab et al. 2010, Anokye et al. 2014); B. balcooa, B. tulda, and B. salarkhanii grown in Bangladesh (Kamruzzaman et al. 2008); and G. atter grown in Indonesia (Marsoem et al. 2015). On the other hand, basic densities tended to increase from the base to the top of the culm. Variations in the basic 
Table 4. A comparison of linear mixed-effects models in the green moisture content of three bamboo species with sites and, or individual culms as random effects.

\begin{tabular}{|c|c|c|c|c|c|c|c|c|}
\hline \multirow{2}{*}{ Species } & \multirow{2}{*}{$\begin{array}{l}\text { Model } \\
\text { ranking }\end{array}$} & \multicolumn{2}{|c|}{ Random slope } & \multicolumn{2}{|c|}{ Random intercept } & \multirow{2}{*}{ AIC } & \multirow{2}{*}{$\Delta \mathrm{AIC}$} & \multirow{2}{*}{$R^{2}$} \\
\hline & & Site & Culm & Site & Culm & & & \\
\hline \multirow{10}{*}{$\begin{array}{c}\text { Bambusa } \\
\text { vulgaris }\end{array}$} & $1 \mathrm{st}$ & & + & & + & 1220.131 & 0 & 0.944 \\
\hline & 2 nd & + & + & & + & 1220.828 & 0.697 & 0.852 \\
\hline & $3 \mathrm{rd}$ & & + & + & + & 1220.894 & 0.763 & 0.944 \\
\hline & 4 th & + & + & + & + & 1221.209 & 1.078 & 0.944 \\
\hline & 5 th & + & & + & + & 1250.837 & 30.706 & 0.830 \\
\hline & 6th & + & & & + & 1251.119 & 30.988 & 0.608 \\
\hline & 7 th & & & & + & 1252.119 & 31.988 & 0.847 \\
\hline & 8th & & & + & + & 1254.086 & 33.955 & 0.944 \\
\hline & 9th & & + & + & & 1335.442 & 115.311 & 0.830 \\
\hline & 10th & & + & & & 1343.221 & 123.090 & 0.470 \\
\hline \multirow{10}{*}{$\begin{array}{l}\text { Bambusa } \\
\text { maculata }\end{array}$} & 1st & & + & & + & 1174.238 & 0 & 0.930 \\
\hline & 2 nd & & + & + & + & 1174.933 & 0.695 & 0.931 \\
\hline & $3 \mathrm{rd}$ & + & + & & + & 1176.231 & 1.993 & 0.931 \\
\hline & 4th & + & + & + & + & 1176.795 & 2.557 & 0.931 \\
\hline & 5 th & & & & + & 1182.903 & 8.665 & 0.891 \\
\hline & 6th & & & + & + & 1184.297 & 10.059 & 0.892 \\
\hline & 7 th & + & & & + & 1184.693 & 10.455 & 0.893 \\
\hline & 8th & + & & + & + & 1185.567 & 11.329 & 0.895 \\
\hline & 9th & & + & + & & 1287.056 & 112.818 & 0.706 \\
\hline & 10th & & + & & & 1298.697 & 124.459 & 0.592 \\
\hline \multirow{10}{*}{$\begin{array}{c}\text { Gigantochloa } \\
\text { atter }\end{array}$} & 1st & + & & + & + & 1189.973 & 0 & 0.928 \\
\hline & 2nd & + & + & + & + & 1191.030 & 1.057 & 0.937 \\
\hline & $3 \mathrm{rd}$ & + & & & + & 1202.631 & 12.658 & 0.927 \\
\hline & 4th & + & + & & + & 1202.781 & 12.808 & 0.939 \\
\hline & 5 th & & + & + & + & 1207.716 & 17.743 & 0.939 \\
\hline & 6th & & + & & + & 1214.290 & 24.317 & 0.936 \\
\hline & 7 th & & & + & + & 1215.625 & 25.652 & 0.899 \\
\hline & 8th & & & & + & 1217.999 & 28.026 & 0.899 \\
\hline & 9th & & + & + & & 1314.135 & 124.162 & 0.765 \\
\hline & 10th & + & + & + & & 1315.426 & 125.453 & 0.774 \\
\hline
\end{tabular}

Note: AIC, Akaike information criterion; $\triangle \mathrm{AIC}$, change in AIC compared to the model with minimum AIC (1st place in 'Model ranking'); $R^{2}$, model-based coefficient of determination. The symbol of ' + ' indicates the parameters included in the model. The $\Delta \mathrm{AIC} \leq 2$ indicate no significant differences between models and a simpler model with fewer parameters is preferred. Bold model ranking represents the best model.

densities in the present study were also the same as those reported in B. vulgaris (Wahab et al. 2010), B. vulgaris 'Vittata' (Vetter et al. 2015), B. rigida (Huang et al. 2014), and G. atter (Marsoem et al. 2015).

\section{Geographic variations}

Fig. 4 shows the variance component ratio of the random-effect parameters estimated by the intercept-only linear mixed-effects model for the fixed mean values of green moisture content and basic density in the three bamboo species. Among three species, the variance component ratio of the site was accounted for around or below $10 \%$ for the green moisture content and basic density in B. vulgaris and B. maculata. In contrast, the site variance component ratio in $G$. atter was larger than the other two species: $18.6 \%$ and $26.5 \%$ for green moisture content and basic density. Relatively higher variance component ratio of site in G. atter might be related to the model selection of longitudinal variations for two properties (Tables 4 and 5). These results suggested that main reasons for variation of 
Table 5. A comparison of linear mixed-effects models in the basic density of three bamboo species with sites and, or individual culms as random effects.

\begin{tabular}{|c|c|c|c|c|c|c|c|c|}
\hline \multirow{2}{*}{ Species } & \multirow{2}{*}{$\begin{array}{l}\text { Model } \\
\text { ranking }\end{array}$} & \multicolumn{2}{|c|}{ Random slope } & \multicolumn{2}{|c|}{ Random intercept } & \multirow{2}{*}{ AIC } & \multirow{2}{*}{$\Delta \mathrm{AIC}$} & \multirow{2}{*}{$R^{2}$} \\
\hline & & Site & Culm & Site & Culm & & & \\
\hline \multirow{10}{*}{$\begin{array}{c}\text { Bambusa } \\
\text { vulgaris }\end{array}$} & 1st & + & + & + & + & -500.819 & 0 & 0.936 \\
\hline & $2 \mathrm{nd}$ & & + & + & + & -498.733 & 2.086 & 0.936 \\
\hline & $3 \mathrm{rd}$ & + & + & & + & -497.336 & 3.483 & 0.936 \\
\hline & 4 th & & + & & + & -496.328 & 4.491 & 0.935 \\
\hline & 5 th & + & & + & + & -472.977 & 27.842 & 0.860 \\
\hline & 6th & + & & & + & -469.518 & 31.300 & 0.855 \\
\hline & 7 th & & & & + & -464.289 & 36.531 & 0.828 \\
\hline & 8th & & & + & + & -463.389 & 37.430 & 0.829 \\
\hline & 9th & & + & + & & -405.674 & 95.145 & 0.712 \\
\hline & 10th & + & + & + & & -403.856 & 96.963 & 0.719 \\
\hline \multirow{10}{*}{$\begin{array}{l}\text { Bambusa } \\
\text { maculata }\end{array}$} & $1 \mathrm{st}$ & & + & & + & -499.322 & 0 & 0.873 \\
\hline & 2nd & & & & + & -498.647 & 0.675 & 0.849 \\
\hline & $3 \mathrm{rd}$ & & + & + & + & -497.517 & 1.805 & 0.874 \\
\hline & 4 th & & & + & + & -497.181 & 2.141 & 0.849 \\
\hline & 5 th & + & & & + & -497.181 & 2.140 & 0.853 \\
\hline & 6th & + & + & & + & -496.693 & 2.629 & 0.873 \\
\hline & 7 th & + & + & + & + & -495.827 & 3.495 & 0.875 \\
\hline & 8th & + & & + & + & -495.402 & 3.920 & 0.854 \\
\hline & 9th & & + & + & & -414.244 & 85.078 & 0.643 \\
\hline & 10th & & + & & & -409.462 & 89.860 & 0.561 \\
\hline \multirow{10}{*}{$\begin{array}{l}\text { Gigantochloa } \\
\text { atter }\end{array}$} & 1 st & + & + & + & + & -545.660 & 0 & 0.933 \\
\hline & 2nd & & + & + & + & -545.384 & 0.276 & 0.932 \\
\hline & $3 \mathrm{rd}$ & + & & + & + & -541.455 & 4.205 & 0.920 \\
\hline & 4 th & & & + & + & -538.500 & 7.160 & 0.912 \\
\hline & 5 th & & + & & + & -536.036 & 9.624 & 0.928 \\
\hline & 6th & + & + & & + & -535.003 & 10.657 & 0.930 \\
\hline & 7 th & + & & & + & -533.368 & 12.292 & 0.917 \\
\hline & 8th & & & & + & -533.139 & 12.521 & 0.911 \\
\hline & 9th & & + & + & & -477.450 & 68.210 & 0.853 \\
\hline & 10th & + & + & & & -426.766 & 118.894 & 0.695 \\
\hline
\end{tabular}

Note: AIC, Akaike information criterion; $\triangle \mathrm{AIC}$, change in AIC compared to the model with minimum AIC (1st place in 'Model ranking'); $R^{2}$, model-based coefficient of determination.

The symbol of ' + ' indicates the parameters included in the model. The $\Delta \mathrm{AIC} \leq 2$ indicate no significant differences between models and simpler model with fewer parameters is preferred. Bold model ranking represents the best model.

green moisture content and basic density were individual culm rather than site for three native bamboo species naturally grown in Lombok Island. However, G. atter had relatively large geographic variations for green moisture content and basic density compared to remained two species.

\section{CONCLUSIONS}

Longitudinal and geographic variations in the green moisture content and basic density of bamboo culm were evaluated by a linear mixed-effects model in three bamboo species (B. vulgaris, B. maculata, and G. atter) naturally grown in four locations in Lombok Island, Indonesia. The characteristics of the three bamboo species can be summarized as follows: 1) the two Bambusa species have similar culm sizes (diameter and height) but differing culm thicknesses, 2) B. vulgaris has the thickest culm among the three species, and 3) G. atter has the largest culm size among the three species but has thinner culm compared with B. vulgaris. The mean green moisture contents and 


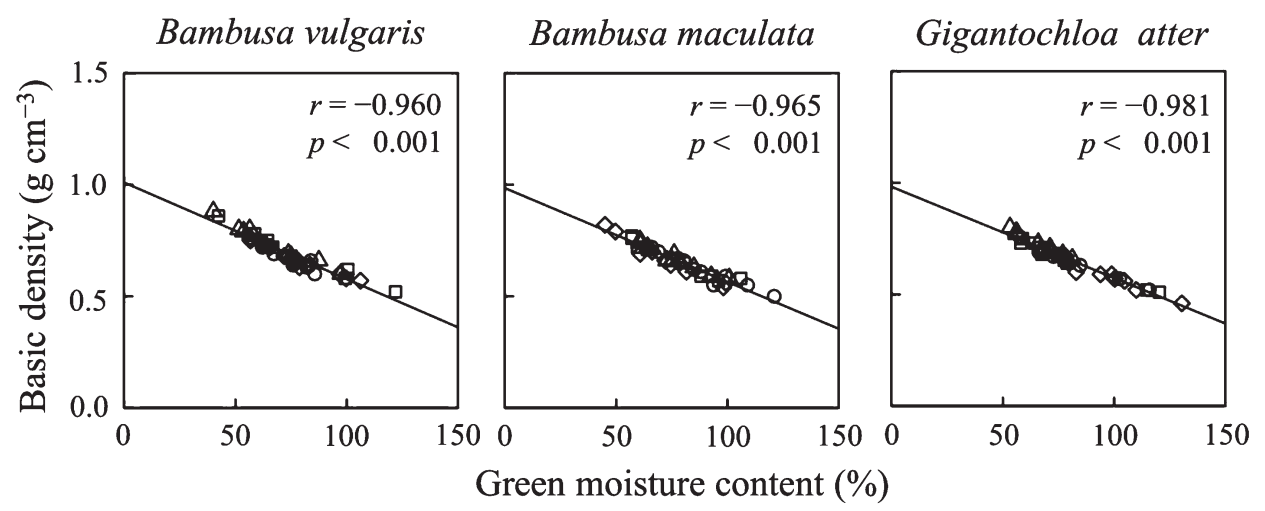

Fig. 2. Relationships between green moisture content and basic density of three bamboo species.

Note: Number of samples $=40$ individual culms; $r$, correlation coefficient; $p, p$-value. The symbol circles, squares, diamonds, and triangles indicate the data at Site I, II, III, and IV, respectively.
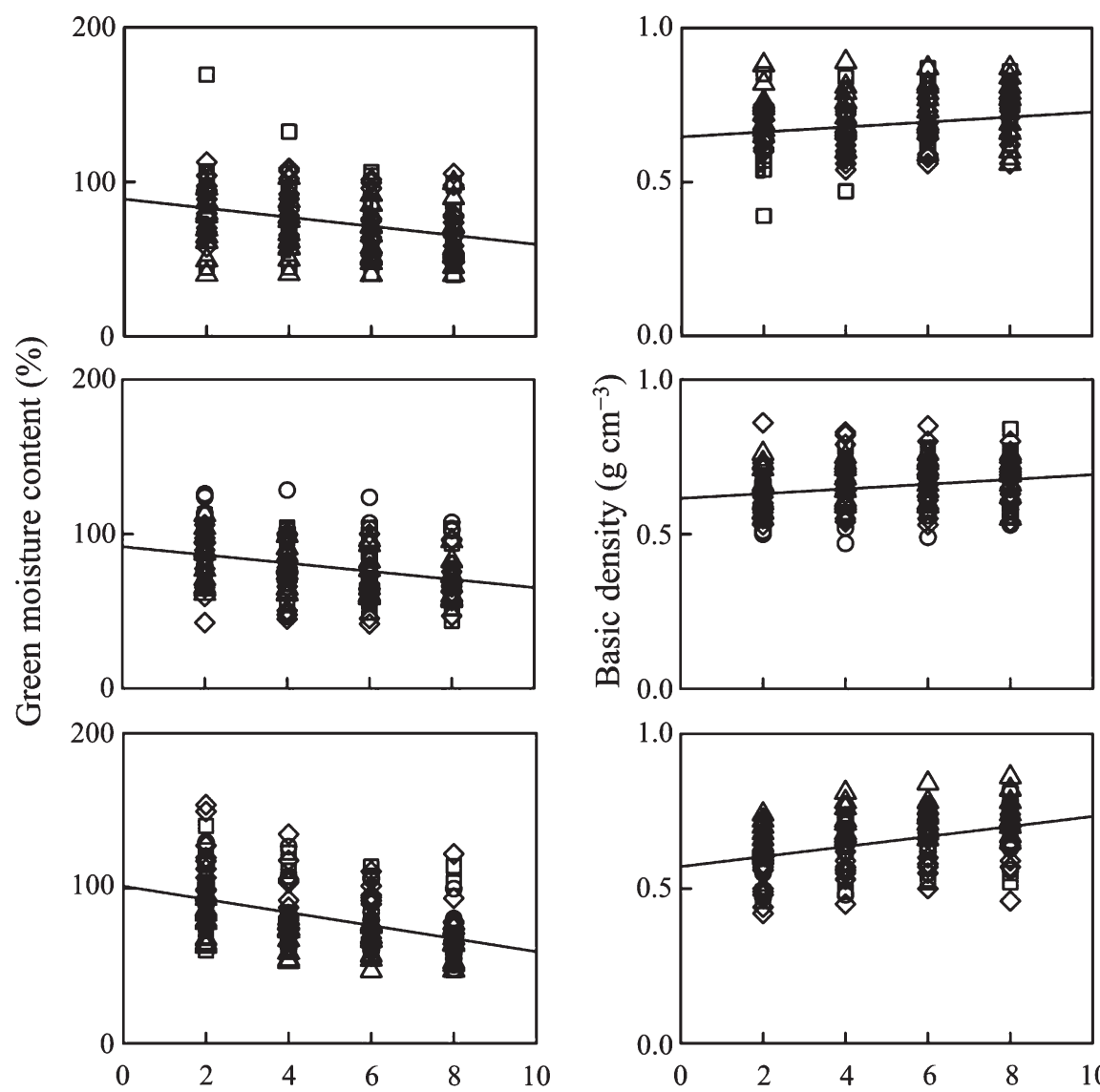

\section{Bambusa} vulgaris

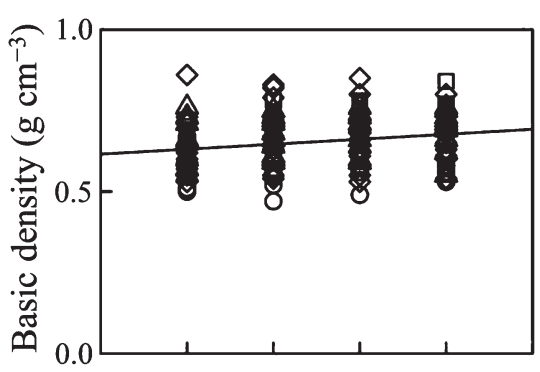

Bambusa maculata

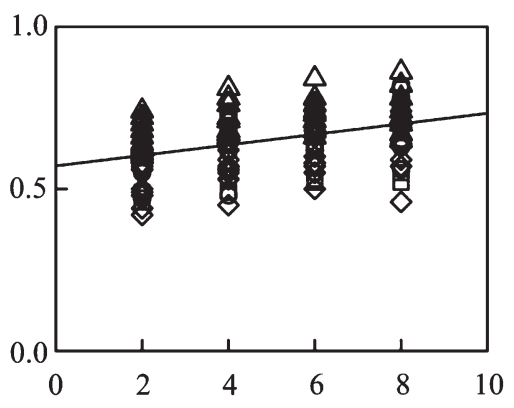

Gigantochloa atter

Height position (m)

Fig. 3. Longitudinal variations of green moisture content and basic density of three bamboo species.

Note: Number of samples $=40$ individual culms. Each solid line indicates the regression line based on the linear mixed-effects model with first ranked model listed in Tables 4 and 5. The symbols of circles, squares, diamonds, and triangles in each figure indicate the data at Site I, II, III, and IV, respectively. 
Table 6. Parameter estimates, standard errors, $t$-values, and $p$-values of the fixed-effect parameters obtained from the best model for longitudinal variation of green moisture content and basic density.

\begin{tabular}{ccccccc}
\hline Properties & Species & Fixed-effect parameters & Estimate & S.E. & $t$-value & $p$-value \\
\hline & B. vulgaris & $\beta_{0}$ & -2.923 & 0.430 & -6.798 & $<0.001$ \\
Green & & $\beta_{1}$ & 88.790 & 3.863 & 22.986 & $<0.001$ \\
moisture & B. maculata & $\beta_{0}$ & -2.642 & 0.278 & -9.494 & $<0.001$ \\
content & & $\beta_{1}$ & 91.688 & 3.061 & 29.950 & $<0.001$ \\
& G. atter & $\beta_{0}$ & -4.237 & 0.835 & -5.077 & 0.015 \\
& & $\beta_{1}$ & 101.441 & 9.336 & 10.866 & 0.002 \\
\hline \multirow{2}{*}{ Basic } & B. vulgaris & $\beta_{0}$ & 0.008 & 0.003 & 2.393 & 0.097 \\
density & \multirow{2}{*}{ maculata } & $\beta_{1}$ & 0.647 & 0.030 & 21.235 & $<0.001$ \\
& \multirow{2}{*}{ G. atter } & $\beta_{0}$ & 0.008 & 0.001 & 6.751 & $<0.001$ \\
& & $\beta_{1}$ & 0.616 & 0.013 & 46.336 & $<0.001$ \\
& $\beta_{0}$ & 0.016 & 0.001 & 13.780 & $<0.001$ \\
\hline
\end{tabular}

Note: $\beta_{0}$, the fixed slope; $\beta_{1}$, the fixed intercept; S.E., standard error.

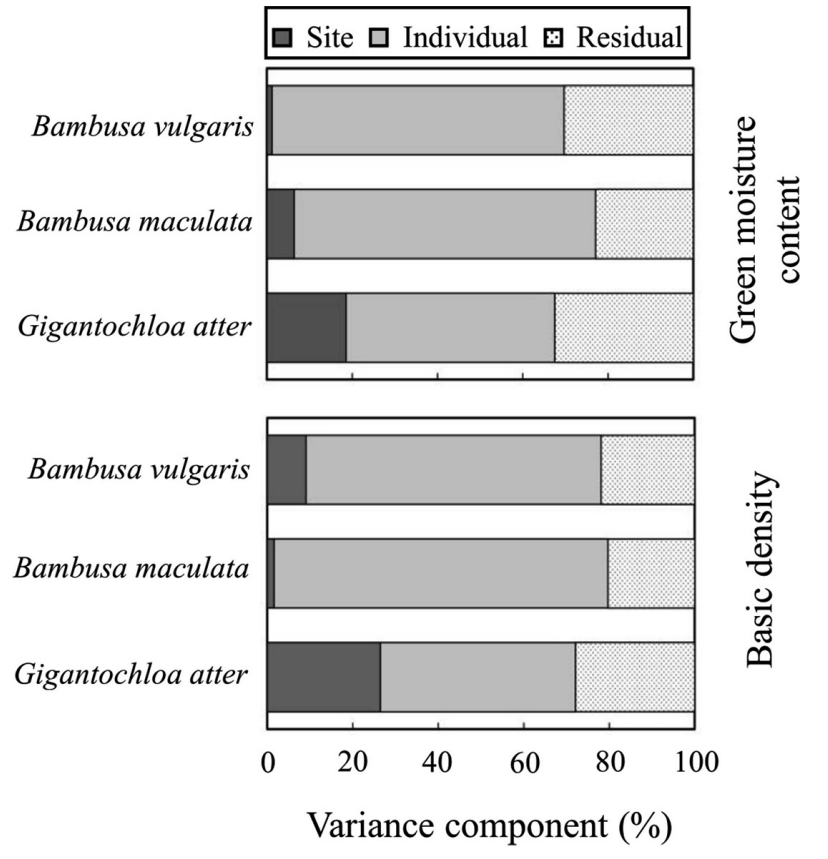

Fig. 4. Variance component ratio of site and individual culm as the random effects in the intercept-only linear mixedeffect model of green moisture content and basic density of three bamboo species.

basic densities of B. vulgaris, B. maculata, and G. atter were $74.2 \%$ and $0.69 \mathrm{~g} \mathrm{~cm}^{-3}, 78.5 \%$ and $0.65 \mathrm{~g} \mathrm{~cm}^{-3}$, and $80.3 \%$ and $0.65 \mathrm{~g} \mathrm{~cm}^{-3}$, respectively. No significant differences in the mean values of both properties among the three species were found. Significant negative correlations between the green moisture content and basic density of the three tested species were found. The green moisture content decreased with an increase in culm height, whereas the basic density tended to increase from the base to the top of the culm for all three species. The results of the variance component ratio estimated by the intercept-only linear mixed-effects models indicated that the main reasons for variations of the green moisture content and basic density of bamboo culm in three bamboo species naturally grown in Lombok Island, Indonesia were variabilities among the individual culm. However, G. atter had relatively large geographic variations in these properties compared to remained two species.

ACKNOWLEDGEMENTS The authors would like to thank Mr. L. Ari Hadi Satria, Mr. M. Firmansyah Akbar, Mr. I Wayan Swastana, Ms. Turmiya Fathal Adawi, and Mr. Habibie for providing assistance during the field sampling and laboratory experiments.

\section{REFERENCE}

Aguinsatan RG, Razal RA, Carandang MG, Peralta EK. 2019. Site influence on the morphological, physical, and mechanical properties of giant bamboo (Dendrocalamus asper) in Bukidnon province, Mindanao, Philippines. Journal of Tropical Forest Science 31: 99-107.

Akaike H. 1998. Information theory and an extension of the maximum likelihood principle. In: Parzen E, Tanabe K, Kitagawa G. (eds) Selected papers of Hirotugu Akaike. Springer Series in Statistics (Perspectives in Statistics). Springer, New York. 199-213.

Akinlabi ET, Anane-Fenin K, Akwada DR. 2017. Properties of bamboo. Bamboo the multi purpose plant. Springer International Publishing, Switzerland. 87-98. 
Anokye R, Kalong RM, Bakar ES, Ratnasingam J, Jawaid M, Awang K. 2014. Variations in moisture content affect the shrinkage of Gigantochloa scortechinii and Bambusa vulgaris at different heights of the bamboo culm. BioResources 9: 74847493.

Auty D, Gardiner BA, Achim A, Moore JR, Cameron AD. 2013. Models for predicting microfibril angle variation in Scots pine. Annals of Forest Science 70: 209-218.

Bae JS, Kim C, Kim YS, Latifah S, Afifi M, Fisher LA, Lee SM, Kim IA, Kang J, Kim R, Kim JS. 2014. Opportunities for implementing $R E D D+$ to enhance sustainable forest management and improve livelihoods in Lombok, NTB, Indonesia. Center for International Forestry Research. http:// www.jstor.org/stable/resrep02354 (cited September 30, 2021).

Barnett JR, Jeronimidis G. 2003. Wood quality and its biological basis. Blackwell Publishing, Oxford.

Bates D, Mächler M, Bolker BM, Walker SC. 2015. Fitting linear mixed-effects models using 1me4. Journal of Statistical Software 67: 1-48.

Burnham KP, Anderson DR. 2004. Multimodel inference: understanding AIC and BIC in Model Selection. Sociological Methods and Research 33: 261-304.

Chaowana P. 2013. Bamboo: an alternative raw material for wood and wood-based composites. Journal of Materials Science Research 2: 90-102.

Grosser D, Liese W. 1971. On the anatomy of Asian bamboos, with special reference to their vascular bundles. Wood Science and Technology 5: 290-312.

Hisham HN, Othman S, Rokiah H, Latif MA, Ani S, Tamizi MM. 2006. Characterization of bamboo Gigantochloa scortechinii at different ages. Journal of Tropical Forest Science 18: 236242.

Huang XY, Qi JQ, Xie JL, Hao JF, Qin BD, Chen SM. 2015. Variation in anatomical characteristics of bamboo, Bambusa rigida. Sains Malaysiana 44: 17-23.

Huang XY, Xie JL, Qi JQ, Hao JF, Zhou N. 2014. Effect of accelerated aging on selected physical and mechanical properties of Bambusa rigida bamboo. European Journal of Wood and Wood Products 72: 547-549.

Kamruzzaman M, Saha SK, Bose AK, Islam MN. 2008. Effects of age and height on physical and mechanical properties of bamboo. Journal of Tropical Forest Science 20: 211-217.

Kleinhenz V, Midmore DJ. 2001. Aspects of bamboo agronomy. Advances in Agronomy 74: 99-153.

Liese W. 1987. Research on bamboo. Wood Science and Technology 21: 189-209.

Liese W, Kohl M. 2015. Bamboo The plant and its uses. Springer International Publishing, Switzerland.

Liu P, Zhou Q, Jiang N, Zhang H, Tian J. 2020. Fundamental research on tensile properties of Phyllostachys bamboo. Results in Materials 7: 1-6.

Marsoem SN, Setiaji F, Kim NH, Sulistyo J, Irawati D, Nugroho WD, Pertiwi YAB. 2015. Fiber morphology and physical characteristics of Gigantochloa atter at three different ages and heights of culms for better utilization. Journal of the Korean Wood Science and Technology 43: 145-155.
Mohmod AL, Ariffin WTW, Ahmad F. 1990. Anatomical features and mechanical properties of three Malaysian bamboos. Journal of Tropical Forest Science 18: 227-234.

Nordahlia AS, Uyup MKA, Husain H, Mohmod AL, Awalludin MF. 2019. Anatomical, physical, and mechanical properties of thirteen Malaysian bamboo species. BioResources 14: 39253943.

Ogunsanwo OY, Terziev N, Panov D, Daniel G. 2015. Bamboo (Bambusa vulgaris Schrad.) from moist forest and derived savanna locations in south west Nigeria - properties and gluability. BioResources 10: 2823-2835.

Peng P, She D. 2014. Isolation, structural characterization, and potential applications of hemicelluloses from bamboo: A review. Carbohydrate Polymers 112: 701-720.

R Core Team. 2020. R: A language and environment for statistical computing. R Foundation for Statistical Computing, Vienna, Austria. URL https://www.R-project.org/.

Sharma B, Gatóo A, Bock M, Ramage M. 2015. Engineered bamboo for structural applications. Construction and Building Materials 81: 66-73.

Sharma M, Sharma CL, Laishram D. 2017. Variation in anatomical and physical properties of some Schizostachyum species of Manipur, India. Journal of the Indian Academy of Wood Science 14: 79-90.

Tan T, Rahbar N, Allameh SM, Kwofie S, Dissmore D, Ghavami K, Soboyejo WO. 2011. Mechanical properties of functionally graded hierarchical bamboo structures. Acta Biomaterialia 7: 3796-3803.

van Dam JE, Elbersen HW, Montaño CMD. 2018. Bamboo production for industrial utilization. In: Alexopoulou E (ed) Perennial grasses for bioenergy and bioproducts. Academic Press, London. 175-216.

van der Lugt P, van den Dobbelsteen AAJF, Janssen JJA. 2006. An environmental, economic and practical assessment of bamboo as a building material for supporting structures. Construction and Building Materials 20: 648-656.

Vetter RE, Ribeiro RAS, Ribeiro MGS, Miranda IPA. 2015. Studies on drying of imperial bamboo. European Journal of Wood and Wood Products 73: 411-414.

Wahab R, Mustapa MT, Sulaiman O, Mohamed A, Hassan A, Khalid I. 2010. Anatomical and physical properties of cultivated two-and four-year-old Bambusa vulgaris. Sains Malaysiana 39: 571-579.

Wahab R, Mustafa MT, Rahman S, Salam MA, Sulaiman O, Sudin M, Rasat MSM. 2012. Relationship between physical, anatomical and strength properties of 3 year old cultivated tropical bamboo Gigantochloa scortechinii. Journal of Agricultural and Biological Science 7: 782-791.

Wang S, Lin S, Li W, Ding Y. 2016. Variations in fiber morphology and chemical components of Dendrocalamus giganteus. Forest Products Journal 66: 319-325.

Wilhelmsson L, Arlinger J, Spångberg K, Lundqvist SO, Grahn T, Hedenberg Ö, Olsson L. 2002. Models for predicting wood properties in stems of Picea abies and Pinus sylvestris in Sweden. Scandinavian Journal of Forest Research 17: 330350 . 
Yang X, Fu M, Xie J, Li Z. 2009. Geographic variation and provenance selection for bamboo wood properties in Bambusa chungii. Journal of Forestry Research 20: 261-267.
Zakikhani P, Zahari R, Sultan MTH, Majid DL. 2017. Morphological, mechanical, and physical properties of four bamboo species. BioResources 12: 2479-2495. 